\title{
The strada litoranea. Mapping colonial rural landscape along the Libyan coastal road.
}

\author{
Alessandro Raffa ${ }^{1,1}$ \\ ${ }^{1}$ Politecnico di Milano, DAStU Department of Architecture and Urban Studies, 20133 Milan, Italy
}

\begin{abstract}
The construction of the Strada Litoranea, the first modern infrastructure of Libya, coincided with an impressive territorial refoundation process. Although the role of this infrastructure in the tourist and rural development had been recognized, the scope and its transformative qualities in the process of modernization of the territory and of invention of a modern landscape has still not been investigated. The present paper illustrates ongoing research, interweaving geography, landscape architecture and architectural planning. Its first aim is to overcome the design-related disciplines previous research, through a less thematic and more 'relational' approach. A process that, starting from the coastal road, can tell the colonial fragments and their relations and reassemble them into a new interpretation of the Libyan peculiar rural landscape. Particularly, the modern strategy for rural development will emerge, also from a topographic point of view. A further element of originality consisted in the mapping process based on multi-scale territorial readings and architectural drawings, both as an instrument of knowledge and of restitution of relations between colonial fragments and strada litoranea. These maps intend to describe the complexity of an ambiguous landscape that oscillates between heterotopia and rooting, designed to be Italian and Libyan together.
\end{abstract}

\section{Introduction}

The present contribution describes ongoing research on the colonial layer of Libya and its traces which are part of the contemporary landscape. In particular, this paper stresses the relationship between the ruralisation process of the country during the Italian Fascist colonial regime and the construction of the first modern infrastructure of the country: the strada litoranea.

The $1882 \mathrm{~km}$ coastal road - completed in 1937 - represented a turning point in the evolution of the Libyan coastal region, opening it to Modernity - not only because it represents the first modern infrastructure of the country, but especially for the transformation processes it accelerated - an act of a territorial re-foundation, which supported agricultural developments and cultural tourism. Although its role in the modernization of the country has been recognized [1, 2, 3], until today its tangible effects on the territory and also in the invention process of an Italian modern

\footnotetext{
${ }^{1}$ Corresponding author: alessandro.raffa@polimi.it
} 
landscape appear not to have been investigated [4]. A systematic survey of the rural materials related to this phase is also missing, depositing so many different artefacts waiting to be re-discovered and understood.

This relational interpretation of the rural traces emerged after a digital mapping process whose objective was to re-compose the colonial fragments and to communicate landscape and architectural qualities and features of the colonial layer in Libya. A Gis-based mapping process has been used to depict the relationship between the colonial ruralisation process and the coastal road, in order to inform future interventions on diffused colonial traces.

The rural-oriented transformation of the territory was linked to the desire to transform Libya into a colony of population, as an antidote to a demographic surplus, emigration and unemployment. The demographic colonization project was structured in 1934 by the governor Italo Balbo. From 1938, according to government forecasts, Libya would have to absorb twenty thousand settlers annually for five years, with a total of one hundred thousand Italians. The outbreak of the Second World War interrupted the assimilation process of the colony to the Motherland, and also halted the process of agricultural enhancement. However, the colonial layer still represents part of the Libyan stratified landscape and continues to influence subsequent changes in the territory.

As documented by the monograph La strada litoranea della Libia [5], the project of the coastal road, which traversed many kilometres of the desert, was accompanied by careful planning of the site and above all by an extensive study of the available resources - in particular water - necessary to complete the coastal road and to settle and cultivate the territory. Between 1936 and 1939, 25 rural settlements, around 3100 colonial houses, $600000 \mathrm{~m}^{3}$ of warehouses, barns and stables were built; 2787 water supply points, $504 \mathrm{~km}$ of pipelines and many other interventions were made to extract around 150000 ha of cultivated land [6].

The fragmented and privately-based rural enhancement process, became more centralized during Balbo's governorship. The colonial authorities took direct control and financed the rural development initiatives. The ruralisation process had a considerable impulse and the rural settlement became the privileged model. Interpreted by the Fascist regime as Italian oases of civilization, the rural settlements had deposited a minor and diffused heritage on the territory made up of roads, crops, aqueducts and cisterns, agricultural silos, farmhouses, farms and directional centres.

\section{Materials and methods: the GIS-based mapping process}

How to return the information collected? How to relate them together? How to communicate the obtained results effectively? How to share them with researchers and professionals? How to integrate future multidisciplinary investigations on Libyan colonial layer? These are the methodological questions.

First of all, it is important to underline a difficult fragmentation of the materials and their dispersion in many archives, both in Italy and Libya, that are often inaccessible or with restrictions for publishing. This represented a difficulty in re-constructing a general framework, but also an opportunity to respond to current needs, especially for a territory whose community [7] needs projects giving knowledge and interpretation of their heritage, seen as a resource for the future. Moving between primary and secondary sources, the research benefited from on-site support in order to verify hypotheses and to document the current status of places. 
Another problem is topographic, that is to identify today the permanence or persistence of colonial traces in the territory; sometimes to rediscover them and to relate their current condition to the archival materials collected. Historical maps at different scales, technical drawings, architectural drawings, maquettes, images and photographs constitute an archive, together with unpublished materials and also represents a large and of course incomplete work that obviously requires implementation over time through additional contributions. Another issue that has been addressed concerns the multi-scalar interpretation of the traces that colonial rural landscape research requires, ranging from the agricultural areas with their waterworks and crops, to directional centres, settlers 'houses and architectural details.

This research, while giving the architectural discipline a central role, also needed to to adopt an interdisciplinary perspective, since the object of investigation requires the contribution of historians, landscape architects, engineers, agronomists and in the future also of other professionals. This multidisciplinary approach, which produced a large amount of data, has placed challenges for their integration, organization, implementation and dissemination.

For these reasons, it was decided to use the SIS (Spatial Information System) technology, based on GIS (Geographical Information System). The latter has been developed to manage not only geospatial or geo-localised data, but also historical, architectural, etc. and share them on the Web through WebGIS. Furthermore, field research represented a fundamental support, for geo-referencing as well as for the interpretation that has been built in parallel with archival research.

The colonial layer was organized according to four themes that an interpretation of the transformations of the Libyan case has identified: agricultural infrastructure, tourism infrastructure, military infrastructure and urban infrastructure. This simplification enabled the identification and isolation of areas and artefacts in order to direct data collection through primary and secondary sources and field research.

It was decided to work first on theme of agricultural transformation because it generated, together with the tracing of the coastal road, a deep re-foundation process in the territory as well as a good place for testing the methodological approach adopted, dealing with the huge amount of interdisciplinary and multi-scalar data.

Concerning rural settlements, their areas, boundaries, fields divisions, crops and persistent elements, and their transformation were first identified. This also revealed their level of conservation and current use, comparing, for example, the urban evolution of some areas that have become urban settlements with others, instead, almost abandoned. It was decided to deepen, in terms of data collection, a focused area of $5 \times 5 \mathrm{~km}$ - this size was determined by a preliminary comparison between the settlements which contained: the directional centre, with its agricultural neighbourhood and the typical farmhouse, the road system, the water system and the cultivation introduced there. This example represents a simplification that allowed a deeper investigation but also the comparison between the 25 rural settlements. Concerning the built space, the centre and the farmhouses in particular, it was possible to reconstruct them in $3 \mathrm{D}$ and, at the same time, to compare them with today through archival research, on site exploration and an open source software, evaluating changes and their state of conservation. Moreover, the three-dimensional models made not only return the colonial morphology of the building possible, but they are also part of the information contained in the database, offering for further studies or interventions. 


\section{Results}

\section{The rural fragments along the strada litoranea}

The rural fragments diffused along the strada litoranea were identified and recomposed together in the mapping process, and are analysed below. After its construction, the coastal road became the main axis for rural enhancement through rural settlements, involving also existing elements. In the colonial discourse, the modernization of the coastal region would have produced a landscape of modernity shaped to be Italian. In this perspective, as already mentioned, rural development had a key role for economic reasons but also for propaganda. As often quoted in newspapers of the time and in public speeches, Fascist Italy achieved in Libya what not even the Roman Empire had managed to do: to unify the region with a modern infrastructure and to make the desert extensively cultivable. Here below the identified elements which built a modern agricultural system are presented by mapped categories (Figures 1-4).

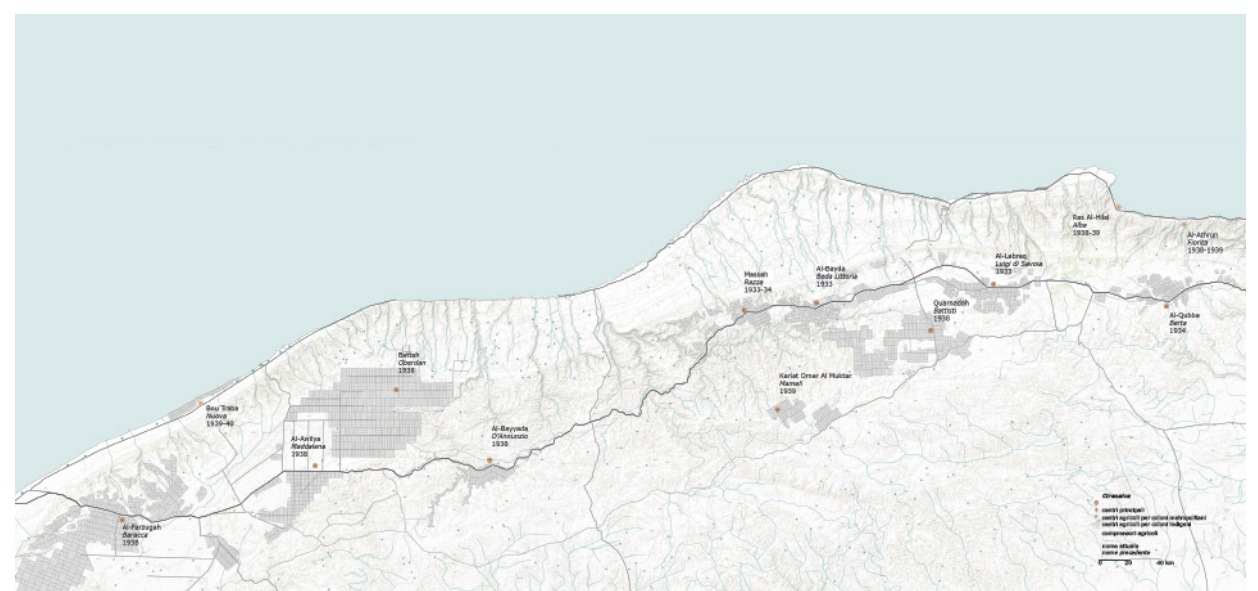

Figure 1. Rural settlement and water system in Cirenaica. Elaboration by the author.

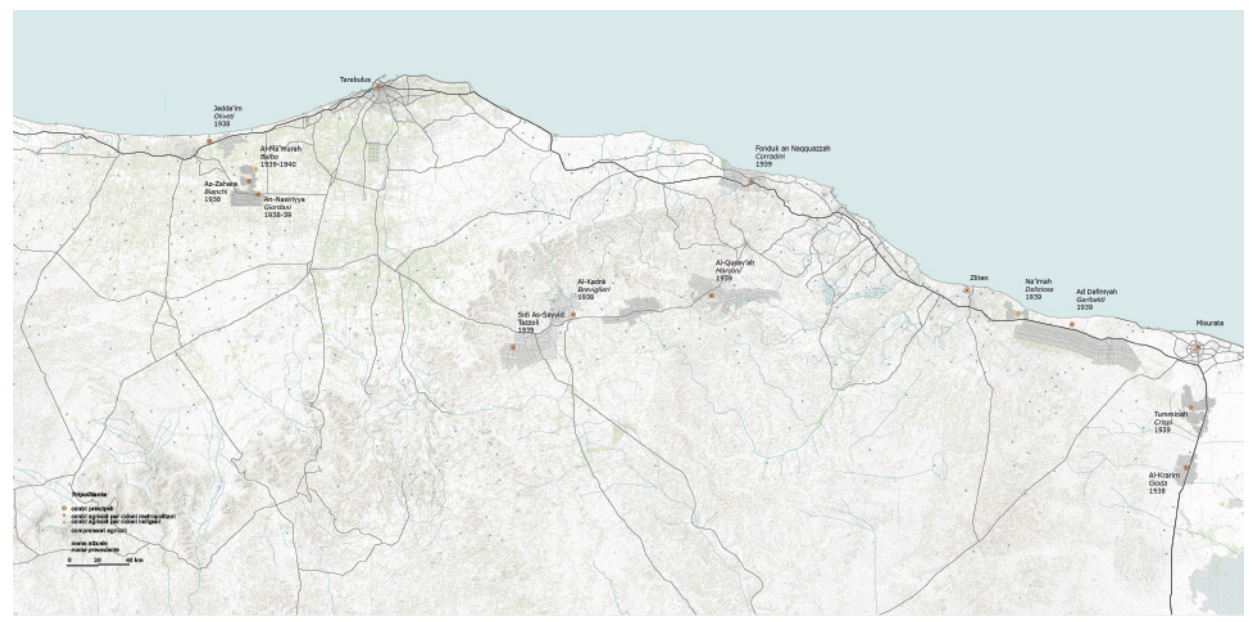

Figure 2. Rural settlement and water system in Tripolitania. Elaboration by the author. 

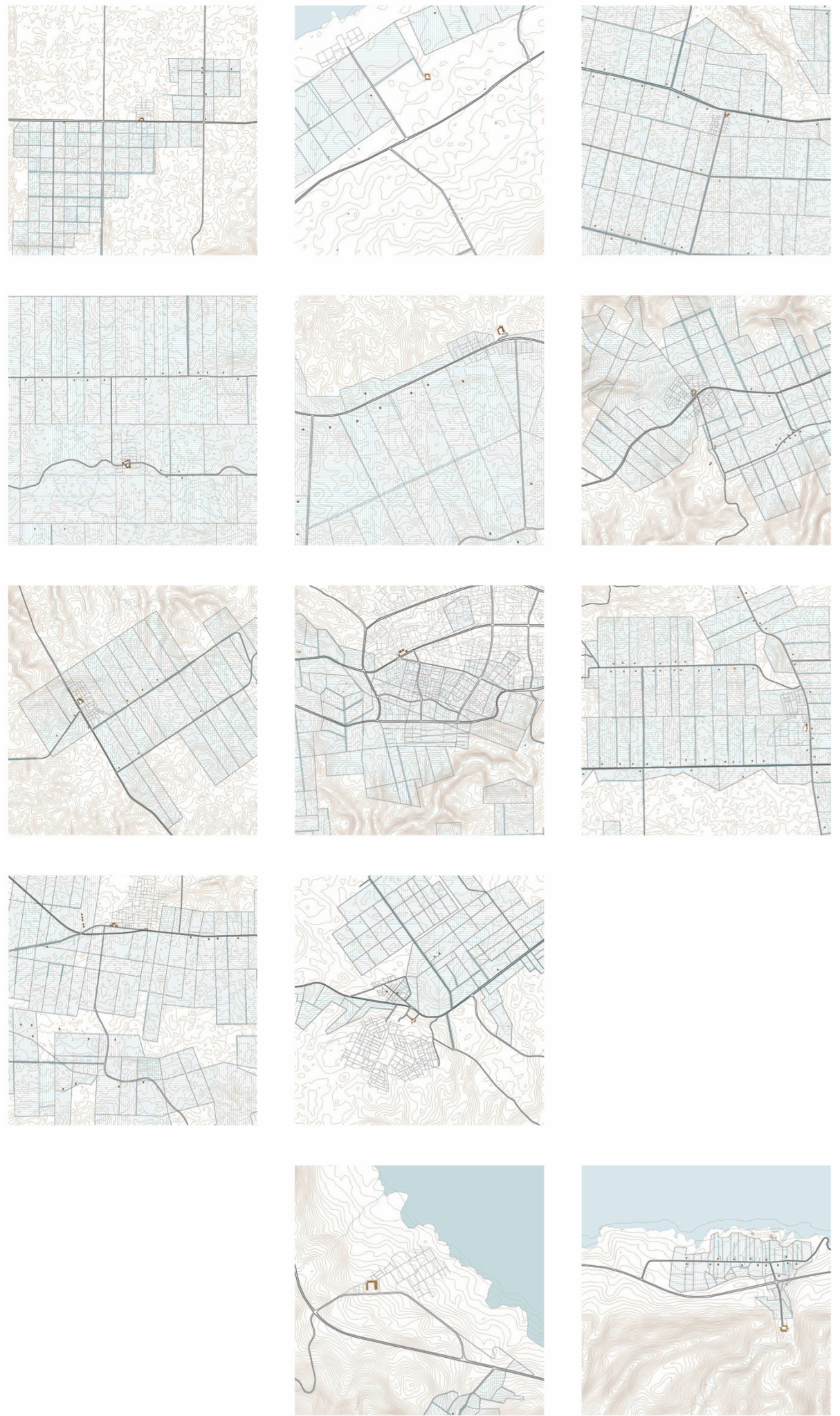

Figure 3. Rural settlements in Tripolitania. Elaboration by the author. 

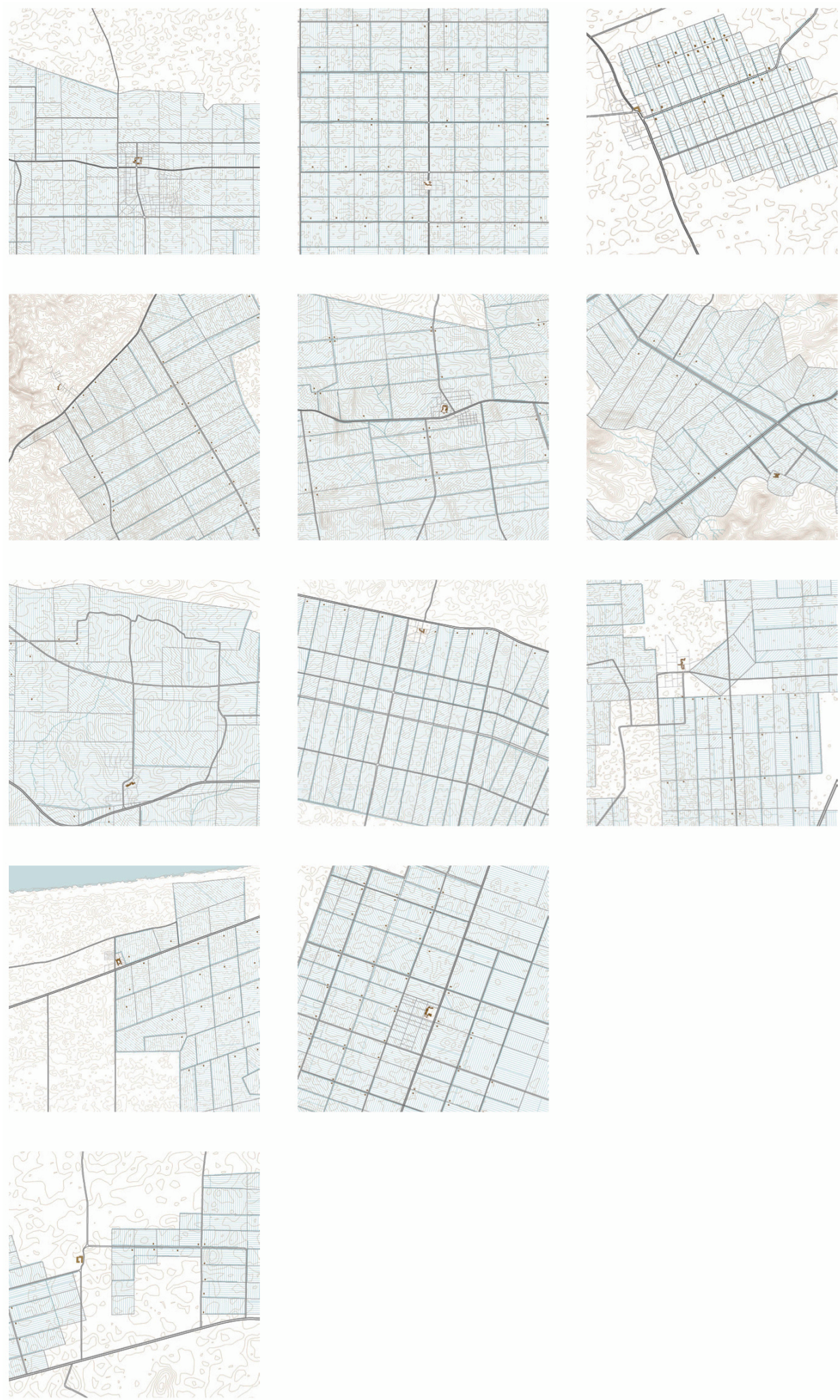

Figure 4 Rural settlements in Cirenaica. Elaboration of the author. 


\section{Water system}

Water supply is the essential prerequisite for agricultural development. Pipelines, aqueducts in embankments, dams, cisterns, wells, wind-powered water pumps partly exploit the groundwater and partly the rainfall. Some of these artefacts, particularly those arranged along the coast, were designed by the architect Florestano Di Fausto and were part of the infrastructural project. In parallel with the water surveys carried out for the construction of the coastal road, the colonial authorities financed research both for finding new water sources as well as using traditional and ancient techniques such as the barriers across existing watercourses.

\section{The system of agricultural companies}

A dense plot, especially in the region of Tripolitania, of medium-sized farms was the first form of land improvement during the colonial occupation. Developed before the completion of the coastal road, architecturally they are characterized by a strong introversion - a kind of fortified farmstead - dictated by a territory which was then still somewhat unstable.

\section{The system of roadman's houses}

Built every $45 \mathrm{~km}$, these assured the control and maintenance of the road, as well as support with services for travellers. They are of two types: a simple roadman's house and another with hospitality services - located more frequent in the desert areas - and they were also designed by the architect Florestano Di Fausto, who was entrusted with the artistic direction of the road and related infrastructure. Equipped with a small vegetable garden for the subsistence of the residents, they were thought of as the nuclei of future farms that would be developed along the coast road.

\section{The system of rural settlements [5]}

Crossed or connected to the coastal road, the settlements formed the main strategy of enhancement of the Fascist colonization phase. Their design was a consequence, on the one side, of a careful planning and management of the available resources and on the other, it was the result of the desire to assimilate the colony to the Motherland. This of course also passed through the transformation of the territory and the construction of an Italian modern landscape on Libyan soil. Between 1934 and 1940, 25 rural settlements were built. In those six years, in fact, the territory underwent a process of rapid transformation that, although implemented by fragments along the coastal road, marked subsequent territorial developments.

The agricultural patterns, in fact, would be the founding element with which future developments have been compared, interpreting them in different ways, but constituting a reference for post-colonial settlement dynamics. The traces, made up of access roads to the settlements, tracks, rows of trees and windbreak hedges, canal and irrigation systems, farmsteads, farmhouses and rural centres, still constitute part of the local identity today. Each rural settlement was organized around the presence of a directional centre that has recurring features in the system and which, in general, was characterized by a tendency to introversion.

These centres represented, from a colonial perspective, outposts of civilization surrounded by an unknown desert, places of experimentation and innovation in 
agriculture, hydraulic engineering and, last but not least, in architecture. From an architectural point of view, this resulted in a planimetric layout which often resulted in introverted buildings (the church, the market, the school, the casa del fascio, the public fountain, etc.) around a central square. The planimetric organization with the use of reinterpreted traditional forms and functions, in the intention of the regime, would have helped the Italian farmers psychologically, giving a sense of protection and security.

A further important element concerns the access road to the rural centre: often connected to the coastal road itself, it also represents the compositional axis of both the settlement and the directional centre.

Another element, in this case visual, between the road and the agricultural centre was the church bell tower that served as a reference both for those who travelled along the strada litoranea and for the settlers who worked and lived in the area; civil towers, agricultural silos and wind-powered water pumps acted in the same way.

The agricultural centres for Italian settlers were a model for another type of settlement destined for the local populations who were forced to settle there. This happened for two reasons: Italian authorities considered nomadism a symptom of backwardness; they also wanted to stem the discontent of the locals who saw their land taken away from the colonizers. Unlike the agricultural centres for Italians, who had a directional role in the settlement, the Muslim villages served as a fondaco (lit. caravanserai), a place to rest in their movements related to pastoral activity and were organized, around a central square. Nothing further, also from a climatic point of view, could be found from their traditional ways of inhabiting the territory.

The importance today of these centres, most of them abandoned, is in the network system they build along the coastal road and the relationships they express through it even today; their strength lies in building this "line", made up of important architecture such as the centres of the settlements - but especially of modest form, like the farmhouses, both able to interpret different contexts and representing even today peculiar elements in the territory.
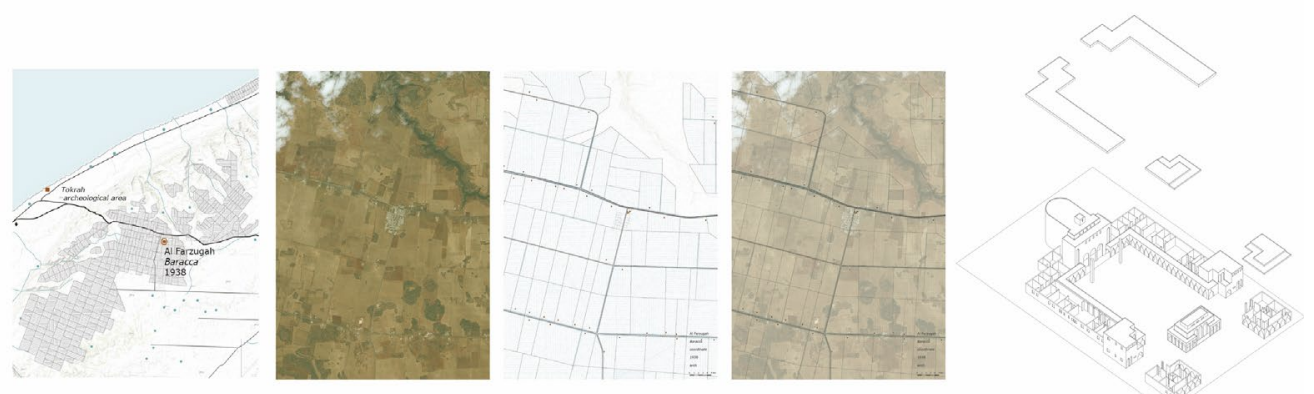

Figure 5 Multi-scalar morphological interpretation from the GIS-based data system.

Elaboration by the author.

\section{The strada litoranea as the main axis for a modern rural (and Italian) landscape}

After mapping the fragments listed earlier, what emerged from the analysis is the refounding role of the Litoranea. Its construction accelerated a deep transformation inside the territory, as quoted in the Resoconti between 1937 and 1940 [8]. In particular, the infrastructure became the main axis for rural development. This emerged from a morphological interpretation of the GIS-based maps (Figure 5). The settlement pattern was often orientated parallel or perpendicular to the Litoranea, or sometimes the coastal 
road represented the main road of the rural area. Their centres were often crossed by the coastal road or a tree-lined path led suggestively to them. The rural centre itself, the bell towers or agricultural silos were thought to be visual references for those who travelled along the coast or worked in the fields. The pure, white volumes of the directional centres, the farmhouses and the roadman's houses acted strategically in the same way: they become reference points for the Italians living there or travelling along the Litoranea. White and simple houses and green cultivated land formed a heterotopic linear landscape along the coastal road, shaped as one of the southernmost Italian regions. The construction of the Litoranea also produced an increase of connections between existing oases, farms, private settlements and the coastal road. The implementation of both the road and the water supply systems created the conditions to support the demographic colonization that, in the Fascist authorities forecast, would had transformed the entire coastal region to a modern Italian rural landscape. In this perspective, the 25 rural settlements and roadman's houses with their water supply system and road connection to the Litoranea were part of a progressive ruralisation process of the coastal region: the rural settlements, as well as the roadman's houses, already underwent processes of cultivated land expansions during the last years before the Second World War.

What emerged also is that, in the second half of the Thirties, the colonial policy towards rural colonization changed, as well as the way to design the landscape: the stricter public control over the ruralisation process, also gave a precise direction to the territorial evolution.

The design and construction of the Strada Litoranea by the architect Florestano di Fausto and the villages built by Di Segni, Pellegrini etc. show a modern colonial approach to infrastructure and landscape design. Urban and architectural design also revealed, even in their specific conditions, the existence of a common ground in interpreting the territory through architecture.

Beside the functional programme of the directional centre - which was almost the same - for example, the majority of them shared many spatial and architectural elements. The objective was from one side to create a reassuring environment for settlers but also to express the Italian presence through the reinterpretation of the Italian Mediterranean tradition. This was also achieved with archaeology, tourism facilities, military structures etc., but what affected the territory the most was the ruralisation process. The importance today of these settlements and rural centres, most of them now abandoned or underused, is in the network system they build with the coastal road and the relations they express to it, even today. Their strength lies in building this "line", made up of modest rural elements, like the farmhouses but also important architecture able both to interpret different contexts and representing, even today, peculiar elements in the territory.

Considering the rural modern landscape of Libya out of its physical context and out of its complex relational network would mean not understanding its primary reason. The multidisciplinary approach and the GIS-based mapping system enables us to investigate and communicate this founding relationship between the rural settlements and artefacts with the Strada Litoranea.

\section{Short resume}

Alessandro Raffa. PhD Architect. Adjunct professor at School of Architecture, Urban Planning Construction Engineering at Politecnico di Milano. His research focuses on Italian colonial urban planning and architecture. 


\section{References}

1. FULLER, M. 1995. Moderns abroad. Architecture, Cities and Italian Imperialism, London - NewYork, Routledge.

DOI: https://doi.org/10.4324/9780203968864

2. MCLAREN, B. 2006. Architecture and Tourism in Italian colonial Libya. An ambivalent modernism, Washinghton, University press.

3. CAPRESI, V. 2009. L'utopia costruita. I centri rurali di fondazione in Libia / The Built Utopia. The Italian Rural Centres Founded in Colonial Libya (1934-1940), Bologna, Bononia University Press.

4. CANALI, F. 2014. "Nuovi fulcri paesaggistici nella Libia di Italo Balbo: la creazione di un nuovo paesaggio della modernità tra infrastruttura e colonizzazione", ASUP - Annuario di Storia dell'Urbanistica e del Paesaggio (special issue "Fulcri urbani e fulcri territoriali tra architettura e paesaggio"), $n^{\circ} 2: 111-201$.

DOI: https://doi.org/2158/1004250

5. La strada litoranea della Libia (1937). Verona, Mondadori.

6. ENTE PER LA COLONIZZAZIONE DELLA LIBIA 1940. Ente per la Colonizzazione della Libia (anno 12-18), Rome, Grafitalia.

7. UNESCO; ICCROM (eds.) 2016. International Expert Meeting on the Safeguard of Libyan Cultural Heritage, Tunis, US Embassy. Retrieved from: www.whc.unesco.org/document/155631 [available on 4 June 2018].

8. Notiziari di informazioni del Governatorato della Libia. Resoconti mensili (19371940). Rome, Archivio Centrale di Stato. 